\title{
( 512$)$
}

\section{SARATOGA SPRINGS AS A RESORT FOR INVALIDS WITH PULMONARY DIFFICULIIES.}

[Communicated for the Boston Medlcal and Surgical Journal.]

AN impression is generally entertained by the public, that our mineral water cannot be drunk by persons suffering with lung difficulties, without injury. If once true, it is not so now. For scveral years past, and since the discovery of the Empire Spring, invalids have been testing its virtues until its eflicacy in pulmonary disease is abundantly proved.

Our healthy climate, with its dry, sandy soil and pine groves, has always been agrceable to the consumptive; but tho water from the various springs, containing more or less iron, conld not long be taken without aggravated symptoms, such as tightness or stricture of the chest, increased cough and fever. But this is not the case with the use of the Empire water. It can be used not only with impunity, but I am convinced more and more strongly, every year, that it is absolutely and unqualifiedly beneficial.

Incipient consumption always improves here, and hundreds now date their first improvement from the use of this water. It improves digestion and assimilation; and nearly all who have been under my care or observation, have gained strength and flesh; and make yearly visits to Saratoga, encouraged by such results.

I am confident the alterative effects of our Empire water (in which there is a large quantity of iodide of potassiun) are such that the appetite and assimilation are improved; the cough and expectoration diminish under its use, the skin becomes warm and healthy, the superficial circulation improves, and the result is an increase of flesh and strength.

My observations aro not confined to one season, or one year's effects, but have extended through a series of ycars. I ain taking the testimony of patients every day as they now return and report their improved health.

I will relate, in another communication, tho details of a $\mathrm{few}$ marked cases, and let others judge if they do not give satisfactory evidence of the curative effect of the Empire Spring water in lung diseases.

L. E. W hiting.

Saratoga Springs, July 7, 1859.

\section{ON THE APPLICATION OF POTASSA FUSA TO THE INTERNAL SURFACE OF THE UTERUS.}

BY horATIO R. STORER, M.D.

[Oommunicated for the Boston Medical and Surgical Journal.]

IT will be recollected that some time since I proposed the application of caustic potash to the interior of the uterus in cortain cases of obstetric disease. 
As the suggestion was then challenged for its apparent temerity, claiming, as it did, to reach cases otherwise incurable, I will add another instance from practice to those already on record in this Journal, and have the less hesitation in stating the case as it is from the experience of a gentleman whom I believe entircly unbiassed.

Tho patient, Mrs. A., of Now London, N. H., I saw in consultation with Dr. MeIntire, of Goshen, during the summer of 1856 . Her symptoms were somewhat obscure, but such, nevertheless, that I had no hesitation in affirming the existence of an intra-uterine polypus, in opposition to the opinions of several physicians who had previously examined the case. Want of time prevented my then operating for its removal, and though earnestly requested to do so, I was unable to revisit the patient. I have lately, however, received from Dr. M. the further history of the case, and shall now quote from his letter, which is dated April $26 \mathrm{th}, 1859$.

"Mrs. A., whom you saw at New London, is now at my house. After sceing various other physicians, among whom was Dr. C., of H., all of them telling her that no polypus was there, and some of them strongly opposing your views of the case and its treatment, she could not be pacified until the os had been dilated and the womb examined beyond doubt: accordingly, three weeks since, I commenced the use of tents. Previously to this, the mass you detected (and of whose existence Dr. M. was convinced, both by siglit and by palpation, during my visit with him), had sloughed off, as I think I wrote you once, leaving a healthy looking os.

"After dilating, I found a fibrous base of the same mass, broadly attached, cxtending nearly to the fundus, and presenting one small spot, about the size of a pea, which was extremely tender. To this I commenced applying potassa fusa, and have made three applications. The mass is now nearly gone, and the patient (who was bedridden) sits up three quarters of the time."

This is the second case of the successful application of potassa fusa to the interior of the uterus reported to me by Dr. MaIntire, to whose courage and good judgment I again cheerfully bear witness.

Blue Hill, Milton, July 13, 1859.

SIMPI. AND COMPOUND COMMINUTED FRACTURE OF THE ARM AND FOREARM.

BY EDWARD WARREN, M.D.

[Communicated for the Boston Medical and Surgical Journal.]

ON the first of August, 1849 , Mr. George W. Shaw was returning from Boston to his residence in Grantville, in the Boston and Worcester Railroad cars. 